\title{
Analisis Sedimentasi dari Pascabencana Banjir Sungai Belanting
}

\author{
Sedimentation Analysis of Post Flood Disaster in Belanting River
}

\author{
I.B. Giri Putra ${ }^{1, a)}$, Yusron Saadi ${ }^{2)}$, Lalu Wirahman ${ }^{3)}$, Salehudin $^{4)}$ \& Syamsul Hidayat ${ }^{5)}$ \\ ${ }^{1,2,3,4,5)}$ Fakultas Teknik, Jurusan Teknik Sipil, Universitas Mataram
}

Korresponden : ${ }^{\text {a) }}$ idabagusgiri66@gmail.com

\begin{abstract}
ABSTRAK
Banjir adalah bencana yang banyak terjadi. Sepanjang tahun 2016, 766 peristiwa banjir dan menyebabkan 147 orang meninggal, 107 orang terluka dan 2,72 juta orang diungsikan dari tempat tinggal mereka dan 30.669 rumah rusak. Rawan banjir banyak terjadi yang tidak pernah terjadi sebelumnya seperti Banjir di wilayah kota Bima dan daerah Belanting dll.

Topan tropis Yvette yang sekarang terletak di Samudra Hindia sekitar $620 \mathrm{~km}$ selatan Denpasar bergerak ke Timur Laut menyebabkan curah hujan yang tinggi di wilayah Indonesia selatan dan hujan yang lebih ekstrim di Nusa Tenggara Barat terutama di daerah Bima, daerah Sumbawa dan daerah Belanting di bagian timur Lombok distrik.

Untuk mengendalikan energi yang dihancurkan air diperlukan penanganan non fisik melalui Konservasi, menjaga ketersediaan, keberlanjutan, karakteristik dan fungsi air untuk menjaga kuantitas dan kualitas air. Hal yang paling mendesak saat ini adalah mengidentifikasi jumlah sedimen setelah banjir bandang berdasarkan transportasi sedimen dan membuat peta data dasar sungai. Peta-peta ini berisi informasi laju transpor sedimen yang terisi dalam kurva laju sedimen untuk digunakan sebagai pedoman untuk menangani setiap kondisi sungai.

Hasil penelitian diperoleh volume sedimen dasar sungai Volume Belanting maksimum yang langsung ditinjau dan diamati adalah $28.623 \mathrm{M}^{3}$ / hari dan persamaan Kurva aliran sungai Belanting yang diamati berdasarkan kondisi debit momen yang terjadi selama penelitian adalah debit aliran yang lebih besar, Qw $=3.304 \mathrm{~m}^{3} / \mathrm{dt}$, sehingga hasil perhitungan transpor material sedimen pada musim kemarau sangat sedikit dibandingkan dengan Sediment Discharge untuk digunakan sebagai material Galian C.
\end{abstract}

Kata Kunci : manajemen sungai, sedimen infrastruktur, transportasi, sungai dan material

\section{PENDAHULUAN}

DAS Belanting merupakan suatu daerah aliran sungai yang menjadi topik permasalahan peningkatan jumlah angkutan sedimen. Meningkatnya jumlah sebaran sedimen dasar pada suatu Daerah Aliran Sungai (DAS) dapat berorientasi pada peningkatan penambangan bahan galian C. Besarnya penambangan yang dilakukan tergantung dari banyaknya sumber bahan galian yang tersedia pasca banjir bandang. Dengan demikian proses penambangan bahan 
galian sendiri akan tetap dilakukan karena itu adalah kebutuhan, namun akan menjadi masalah, ketika eksploitasi itu tidak memperhatikan unsur-unsur penunjang yang ada dan pada akhirnya akan memberikan kerugian pada manusia itu sendiri. Unsur-unsur penunjang yang dimaksud disini berupa karakteristik lingkungan, ketersedian sumber daya alam, serta pengaruhnya terhadap kelangsungan ekosistem di lokasi penambangan tersebut (Anonim, 2012).

Sungai harus dianggap sebagai suatu Aset bagi suatu Wilayah. Oleh karena itu Sungai harus dikelola dengan baik sesuai dengan Prinsip Dasar Manajemen Aset Infrastruktur. Aset Sungai harus dikelola dengan baik, sehingga pemanfaatan sungai bisa dilakukan secara optimal tanpa menimbulkan resiko yang tidak diinginkan (Suprayitno \& Soemitro 2018). Salah satu pemanfaatan sungai adalah Penambangan Galian Tipe C.

Tujuan yang diharapkan dalam penelitian ini adalah untuk membuat suatu peta tangkapan sedimen Sungai Belanting yang berisi informasi tentang jumlah laju angkutan sedimen, karakteristik sedimen dalam penetapan alternatif Galian $\mathrm{C}$ pada sungai tersebut. Peta ini diharapkan dapat digunakan sebagai panduan untuk mengetahui kondisi sedimen dan sungai yang perlu mendapat perhatian sesuai dengan tingkat atau laju angkutan sedimennya. Beberapa indikator yang digunakan adalah adanya persamaan lengkung aliran-sedimen yang memuat hubungan antara debit dan volume sedimen pada Sungai Belanting yang terkandung didalamnya.

\section{TINJAUAN PUSTAKA}

Konsep tentang kontinuitas sedimen pada suatu ruas sungai dalam suatu periode tertentu dinyatakan dengan jumlah sedimen yang masuk kedalam ruas dikurangi jumlah sedimen yang keluar dari ujung sebelah hilir ruas sama dengan jumlah sedimen yang disimpan (store) pada ruas tersebut (Priyantoro, 1987). Sedimen yang masuk kedalam ruas dapat berupa sedimen yang masuk melalui ruas penampang di bagian hulu ruas ditambah masukan dari samping ruas yang merupakan hasil gerusan dari daerah pengaliran dan bantaran banjir (Putra, 2003). Kapasitas angkut sedimen oleh aliran pada ruas sungai menentukan besarnya laju sedimen keluar (Asdak, 2010). Pada kondisi tertentu dengan debit tertentu, kestabilan dasar sungai dapat terjadi, hal ini sering diikuti dengan peristiwa terbentuknya material armouring pada dasar sungai. Dimana material armouring yang dimaksud adalah material dasar yang stabil selama proses pengaliran (Putra, 2008).

\section{Lokasi Penelitian}

Penelitian dilakukan pada Sungai Belanting di Wilayah DAS Nangka yang merupakan salah satu kawasan yang terletak di Wilayah Kabupaten Lombok Timur, Kecamatan Sambelia, Desa Belanting. Untuk mengujian material sedimen dilakukan di Laboratoriaum Hidrolika dan Pantai serta Laboratorium Geologi Teknik Fakultas Teknik Universitas Mataram. 


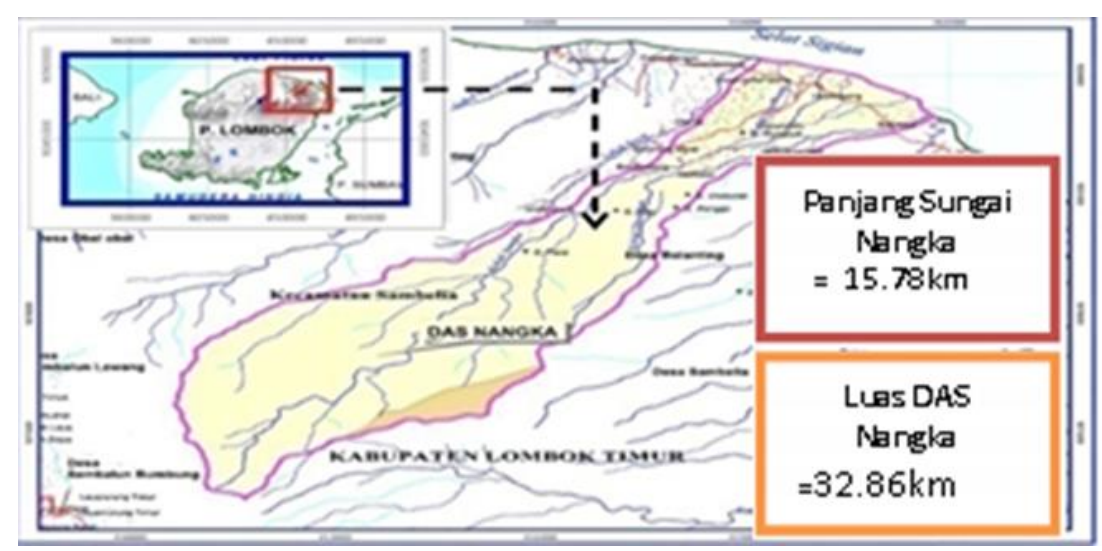

Gambar 1. Peta Lokasi Penelitian

(Sumber : Anonim, 2013)

\section{Lokasi PengambilanSampel}

Sampel diambil 100 meter dari hulu bendung yang diambiil di tiga lokasi berbeda untuk mendapatkan rerata sampel sedimen dasar.

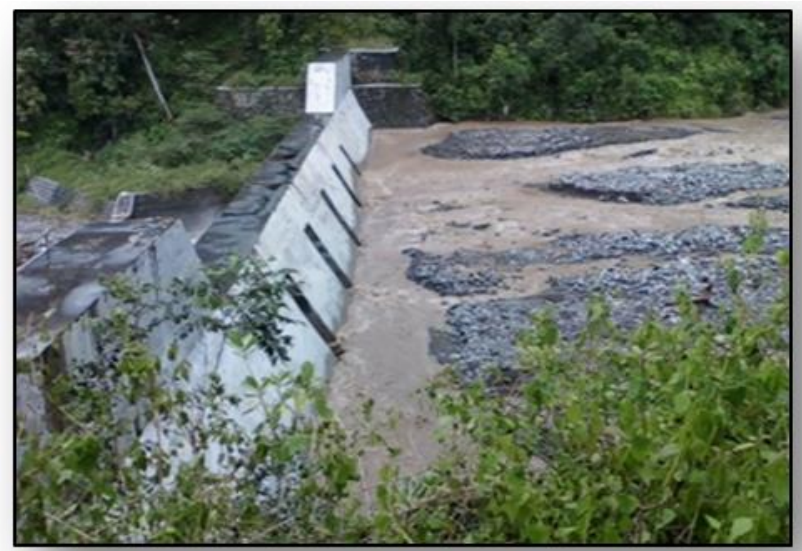

Gambar 2. Lokasi Pengambilan Sampel

\section{ANALISIS PEMBAHASAN}

\section{Sungai Belanting}

Untuk mendapatkan data kecepatan aliran (U), penelitian ini menggunakan alat current meter yang diletakan pada kedalaman $0,6 \mathrm{H}$ pada masing-masing pias dari penampang melintang saluran. Pengukuran kecepatan aliran dengan alat current meter dapat dilihat pada Gambar 3 berikut ini :

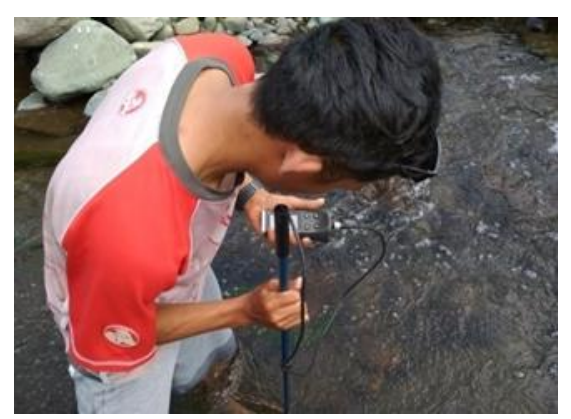


Gambar 3. Pengambilan Data Kecepatan Aliran pada Sungai Belanting

Data kecepatan di penampang melintang Sungai Belanting dengan Current Meter pada musim kemarau dapat dilihat pada Tabel 1, Tabel 2 di bawah ini.

Tabel 1. Hasil Pengukuran Kecepatan Aliran Sungai Belanting pada Survei I

\begin{tabular}{|c|c|c|c|c|c|c|}
\hline \multirow[b]{2}{*}{ Piac } & \multirow[b]{2}{*}{$\mathrm{H}(\mathrm{m})$} & \multicolumn{3}{|c|}{ Kecepatan Pada Titik 0,6 H (m/dt) } & \multirow{2}{*}{$\begin{array}{c}\text { Rata- rata } \\
\text { Per pias } \\
(\mathrm{m} / \mathrm{dt})\end{array}$} & \multirow{2}{*}{$\begin{array}{c}\text { Rata- rata } \\
\text { Total } \\
(\mathrm{m} / \mathrm{dt})\end{array}$} \\
\hline & & $\begin{array}{c}\text { Pengambilan } \\
\text { ke }-1\end{array}$ & $\begin{array}{c}\text { Pengambilan } \\
\text { ke }-2\end{array}$ & $\begin{array}{c}\text { Pengambilan } \\
\text { ke }-3\end{array}$ & & \\
\hline 1 & 0,455 & 0,299 & 0,322 & 0,326 & 0,316 & \multirow{3}{*}{0,637} \\
\hline 2 & 0,432 & 0,586 & 0,633 & 0,584 & 0,601 & \\
\hline 3 & 0,293 & 1,001 & 0,982 & 0,997 & 0,993 & \\
\hline
\end{tabular}

(Sumber: Hasil Survei Lapangan)

Tabel 2. Hasil Pengukuran Kecepatan Aliran Sungai Belanting pada Survei II

\begin{tabular}{|c|c|c|c|c|c|c|}
\hline \multirow[b]{2}{*}{ Pias } & \multirow[b]{2}{*}{$\mathrm{H}(\mathrm{m})$} & \multicolumn{3}{|c|}{ Kecepatan Pada Titik 0,6 H (m/dt) } & \multirow{2}{*}{$\begin{array}{c}\text { Rata- rata } \\
\text { Per pias } \\
\text { (m/dt) }\end{array}$} & \multirow{2}{*}{$\begin{array}{c}\text { Rata- rata } \\
\text { Total } \\
(\mathrm{m} / \mathrm{dt})\end{array}$} \\
\hline & & $\begin{array}{c}\text { Pengambilan } \\
\text { ke }-1\end{array}$ & $\begin{array}{c}\text { Pengambilan } \\
\text { ke }-2\end{array}$ & $\begin{array}{c}\text { Pengambilan } \\
\text { ke }-3\end{array}$ & & \\
\hline 1 & 0,355 & 0,818 & 0,798 & 0,679 & 0,765 & \multirow{3}{*}{0,847} \\
\hline 2 & 0,54 & 0,845 & 0,918 & 0,866 & 0,876 & \\
\hline 3 & 0,29 & 0,872 & 0,903 & 0,927 & 0,901 & \\
\hline
\end{tabular}

(Sumber: Hasil Survei lapangan)

Untuk perhitungan debit aliran Sungai Belanting pada survei survei II caranya sama dengan perhitungan survei I dapat dilihat pada Tabel 3 berikut ini :

Tabel 3. Hasil Perhitungan Debit Aliran Sungai

\begin{tabular}{|c|c|c|c|c|}
\hline $\begin{array}{c}\text { Nama } \\
\text { Sungai }\end{array}$ & $\begin{array}{c}\text { Luas } \\
\text { Penampang } \\
\mathrm{A}\left(\mathrm{m}^{2}\right)\end{array}$ & $\begin{array}{c}\text { Kecepatan } \\
\mathrm{U} \\
(\mathrm{m} / \mathrm{det})\end{array}$ & $\begin{array}{c}\text { Debit } \\
\mathrm{Q} \\
\left(\mathrm{m}^{3} / \mathrm{det}\right)\end{array}$ & Keterangan \\
\hline \hline $\begin{array}{c}\text { Sungai } \\
\text { Belanting }\end{array}$ & 5,188 & 0,637 & 3,304 & Survei I \\
\cline { 2 - 5 } & 6,123 & 0,847 & 5,187 & Survei II \\
\hline
\end{tabular}

Perhitungan Kecepatan Geser Butiran (U*)

Kecepatan geser butiran dihitung berikut ini.

$$
\mathrm{U} *=\sqrt{\mathrm{g} . \mathrm{R} . \mathrm{I}}
$$

Untuk perhitungan kecepatan geser butiran Sungai Belanting pada survei musim kemarau I dapat dilihat pada perhitungan berikut ini.

$$
\begin{aligned}
U^{*} & =\sqrt{\text { g.R.I }} \\
& =\sqrt{9,81 \cdot 0,237 \cdot 0,0,0077} \\
& =0,134 \mathrm{~m} / \mathrm{det}
\end{aligned}
$$


Perhitungan kecepatan geser butiran untuk Sungai Belanting pada survei II caranya sama dengan perhitungan musim kemarau I, hasilnya dapat sebagai berikut :

$$
\begin{aligned}
\mathrm{U}^{*} & =\sqrt{\mathrm{g} \cdot \mathrm{R} \cdot \mathrm{I}} \\
& =\sqrt{9,81 \cdot 0,318 \cdot 0,014} \\
& =0,180 \mathrm{~m} / \mathrm{det}
\end{aligned}
$$

\section{Karakteristik Sedimen}

Untuk mendapatkan distribusi ukuran butiran, maka material sedimen dasar yang didapatkan dioven sampai dalam kondisi kering dan selanjutnya dianalisa dengan menggunakan saringan (no.1.1/4", 1", 3/4”, 1/2", 3/8", 1/4", 2, 6, 8, 10, 20, 40, 60, 80, 100,140 dan 200). Kemudian semua sampel dianalisa gradasi yang hasilnya dapat dilihat pada

\begin{tabular}{|c|c|c|c|c|c|c|c|}
\hline $\begin{array}{c}\text { No } \\
\text { Saringan } \\
\end{array}$ & $\begin{array}{c}\text { Diameter } \\
\text { Butiran }\end{array}$ & $\begin{array}{c}\text { Berat } \\
\text { Saringan }\end{array}$ & $\begin{array}{c}\text { Berat Sampel } \\
\text { Tertahan + } \\
\text { Saringan } \\
\end{array}$ & $\begin{array}{c}\text { Berat } \\
\text { Sampel } \\
\text { Tertahqn } \\
\end{array}$ & $\begin{array}{c}\text { Berat Sampel } \\
\text { KumLolos } \\
\text { Saringan } \\
\end{array}$ & $\begin{array}{c}\text { Persen } \\
\text { Lolos } \\
\text { Saringan } \\
\end{array}$ & Jenis Material \\
\hline & (mm) & (gr) & (gr) & (gr) & (gr) & $(\%)$ & \\
\hline $11 / 4^{\prime \prime}$ & 31,5 & 459,25 & 459,25 & $\mathbf{0}$ & 502,46 & 100,00 & Kerikil berkwarsa \\
\hline $1^{\prime \prime}$ & 25 & 452,79 & 452,79 & $\mathbf{0}$ & 502,46 & 100,00 & Kerikil berkwarsa \\
\hline $3 / 4^{\prime \prime}$ & 19 & 468,88 & 578,77 & 109,89 & 392,57 & 78,13 & Kerikil berkwarsa \\
\hline $1 / 2^{\prime \prime}$ & 12,5 & 450,92 & 518,49 & 67,57 & 325 & 64,68 & Kerikil sedang \\
\hline $3 / 8^{\prime \prime}$ & 9,5 & 442,87 & 466,02 & 23,15 & 301,85 & 60,07 & Kerikil sedang \\
\hline $1 / 4^{\prime \prime}$ & 6,3 & 440,67 & 454,08 & 13,41 & 288,44 & 57,41 & Kerikil halus \\
\hline 4 & 4,8 & 429,17 & 435,99 & 6,82 & 281,62 & 56,05 & Kenikil halus \\
\hline 6 & 3,35 & 411,7 & 424,25 & 12,55 & 269,07 & 53,55 & Kerikil sangat halus \\
\hline 8 & 2,4 & 394,32 & 409,08 & 14,76 & 254,31 & 50,61 & Kerikil sangat halus \\
\hline 10 & 2 & 395,41 & 402,57 & 7,16 & 247,15 & 49,19 & Pasir sangat berkwarsa \\
\hline 20 & 0,85 & 355,64 & 418 & 62,36 & 184,79 & 36,78 & Pasir berkwarsa \\
\hline 40 & 0,425 & 315,66 & 389,32 & 73,66 & 111,13 & 22,12 & Pasir sedang \\
\hline 60 & 0,25 & 285,22 & 342,84 & 57,62 & 53,51 & 10,65 & Pasir sedang \\
\hline 80 & 0,18 & 280,59 & 305,1 & 24,51 & 29 & 5,77 & Pasir halus \\
\hline 100 & 0,15 & 275,97 & 282,83 & 6,86 & 22,14 & 4,41 & Pasir halus \\
\hline 140 & 0,106 & 272,24 & 287,17 & 14,93 & 7,21 & 1,43 & Pasir sangat halus \\
\hline 200 & 0,075 & 268,7 & 273,85 & 5,15 & 2,06 & 0,41 & Pasir sangat halus \\
\hline Pan & & 318,26 & 320,32 & 2,06 & $\mathbf{0}$ & $\mathbf{0 , 0 0}$ & \\
\hline \multicolumn{4}{|c|}{ Total } & 502,46 & & & \\
\hline
\end{tabular}
tabel berikut ini,

Tabel 4. Distribusi Ukuran Butiran Sungai Belanting Musim Kemarau Survei I

PIAS KANAN 1 


\begin{tabular}{|c|c|c|c|c|c|c|c|}
\hline $\begin{array}{c}\text { No } \\
\text { Saringan }\end{array}$ & $\begin{array}{c}\text { Diameter } \\
\text { Butiran }\end{array}$ & $\begin{array}{c}\text { Berat } \\
\text { Saringan }\end{array}$ & $\begin{array}{c}\text { Berat Sampel } \\
\text { Tertahan + } \\
\text { Saringan }\end{array}$ & $\begin{array}{c}\text { Berat } \\
\text { Sampel } \\
\text { Tertahan }\end{array}$ & $\begin{array}{c}\text { Berat Sampel } \\
\text { Kum.Lolos } \\
\text { Saringan }\end{array}$ & $\begin{array}{c}\text { Persen } \\
\text { Lolos } \\
\text { Saringan }\end{array}$ & Jenis Material \\
\hline & (mm) & (gr) & (gr) & (gr) & (gr) & (\%) & \\
\hline 1 1/4" & 31,5 & 459,25 & 459,25 & $\mathbf{0 , 0 0}$ & 506,31 & 100,00 & Kerikil berkwarsa \\
\hline $1 "$ & 25 & 452,79 & 471,09 & 18,30 & 488,01 & 96,39 & Kerikil berkwarsa \\
\hline $3 / 4^{n}$ & 19 & 468,88 & 559,4 & 90,52 & 397,49 & 78,51 & Kerikil berkwarsa \\
\hline $1 / 2^{\pi}$ & 12,5 & 450,92 & 531,01 & 80,09 & 317,4 & 62,69 & Kerikil sedang \\
\hline $3 / 8^{\pi}$ & 9,5 & 442,87 & 461,02 & 18,15 & 299,25 & 59,10 & Kerikil sedang \\
\hline $1 / 4^{\pi}$ & 6,3 & 440,67 & 443,76 & 3,09 & 296,16 & 58,49 & Kerikil halus \\
\hline 4 & 4,8 & 429,17 & 434,31 & 5,14 & 291,02 & 57,48 & Kerikil halus \\
\hline 6 & 3,35 & 411,7 & 421,86 & 10,16 & 280,86 & 55,47 & Kerikil sangat halus \\
\hline 8 & 2,4 & 394,32 & 404,65 & 10,33 & 270,53 & 53,43 & Kerikil sangat halus \\
\hline 10 & 2 & 395,41 & 400,64 & 5,23 & 265,3 & 52,40 & Pasir sangat berkwarsa \\
\hline 20 & 0,85 & 355,64 & 399,67 & 44,03 & 221,27 & 43,70 & Pasir berkwarsa \\
\hline 40 & 0,425 & 315,66 & 367,42 & 51,76 & 169,51 & 33,48 & Pasir sedang \\
\hline 60 & 0,25 & 285,22 & 323,68 & 38,46 & 131,05 & 25,88 & Pasir sedang \\
\hline 80 & $\mathbf{0 , 1 8}$ & 280,59 & 396,69 & 116,10 & 14,95 & 2,95 & Pasir halus \\
\hline 100 & 0,15 & 275,97 & 280,33 & 4,36 & 10,59 & 2,09 & Pasir halus \\
\hline 140 & 0,106 & 272,24 & 279,61 & 7,37 & 3,22 & 0,64 & Pasir sangat hahus \\
\hline 200 & 0,075 & 268,7 & 270,76 & 2,06 & 1,16 & 0,23 & Pasir sangat hahus \\
\hline Pan & & 318,26 & 319,42 & 1,16 & $\mathbf{0}$ & $\mathbf{0 , 0 0}$ & \\
\hline
\end{tabular}

PIAS TENGAH 1

\begin{tabular}{|c|c|c|c|c|c|c|c|}
\hline $\begin{array}{c}\text { No } \\
\text { Saringan }\end{array}$ & $\begin{array}{l}\text { Diameter } \\
\text { Butiran } \\
\end{array}$ & $\begin{array}{c}\text { Berat } \\
\text { Saringan } \\
\end{array}$ & $\begin{array}{c}\text { Berat Sampel } \\
\text { Tertahan + } \\
\text { Saringan } \\
\end{array}$ & $\begin{array}{c}\text { Berat } \\
\text { Sampel } \\
\text { Tertahan }\end{array}$ & $\begin{array}{c}\text { Berat Sampel } \\
\text { Kum_Lolos } \\
\text { Saringan } \\
\end{array}$ & $\begin{array}{c}\text { Persen } \\
\text { Lolos } \\
\text { Saringan } \\
\end{array}$ & Jenis Material \\
\hline & (mm) & (gr) & (gr) & (gr) & (gr) & $(\%)$ & \\
\hline $11 / 4^{\prime \prime}$ & 31,5 & 459,25 & 563,99 & 104,74 & 430,36 & 80,43 & Kerikil berkwarsa \\
\hline $1^{\prime \prime}$ & 25 & 452,79 & 452,79 & $\mathbf{0}$ & 430,36 & 80,43 & Kerikil berkwarsa \\
\hline $3 / 4^{\prime \prime}$ & 19 & 468,88 & 533,65 & 64,77 & 365,59 & 68,32 & Kerikil berkwarsa \\
\hline $1 / 2^{\prime \prime}$ & 12,5 & 450,92 & 533,23 & 82,31 & 283,28 & 52,94 & Kerikil sedang \\
\hline $3 / 8$ " & 9,5 & 442,87 & 461,66 & 18,79 & 264,49 & 49,43 & Kerikil sedang \\
\hline $1 / 4^{\prime \prime}$ & 6,3 & 440,67 & 450,41 & 9,74 & 254,75 & 47,61 & Kerikil hałus \\
\hline 4 & 4,8 & 429,17 & 434,38 & 5,21 & 249,54 & 46,63 & Kerikil hahus \\
\hline 6 & 3,35 & 411,7 & 420,13 & 8,43 & 241,11 & 45,06 & Kerikil sangat hahus \\
\hline 8 & 2,4 & 394,32 & 404,86 & 10,54 & 230,57 & 43,09 & Kerikil sangat halus \\
\hline 10 & 2 & 395,41 & 401,44 & 6,03 & 224,54 & 41,96 & Pasir sangat berkwarsa \\
\hline 20 & 0,85 & 355,64 & 401,6 & 45,96 & 178,58 & 33,37 & Pasir berkwarsa \\
\hline 40 & 0,425 & 315,66 & 381,64 & 65,98 & 112,6 & 21,04 & Pasir sedang \\
\hline 60 & 0,25 & 285,22 & 341,93 & 56,71 & 55,89 & 10,44 & Pasir sedang \\
\hline 80 & 0,18 & 280,59 & 306,95 & 26,36 & 29,53 & 5,52 & Pasir halus \\
\hline 100 & 0,15 & 275,97 & 283,68 & 7,71 & 21,82 & 4,08 & Pasir halus \\
\hline 140 & 0,106 & 272,24 & 287,04 & 14,8 & 7,02 & 1,31 & Pasir sangat halus \\
\hline 200 & 0,075 & 268,7 & 273,42 & 4,72 & 2,3 & 0,43 & Pasir sangat halus \\
\hline Pan & & 318,26 & 320,56 & 2,3 & $-1,13687 \mathrm{E}-13$ & $\mathbf{0 , 0 0}$ & \\
\hline \multicolumn{4}{|c|}{ Total } & 535,1 & & & \\
\hline
\end{tabular}


Dari tabel diatas maka dapat digambarkan grafik komulatif lolos saringan dari masingmasing sampel seperti disajikan pada gambar di bawah ini.

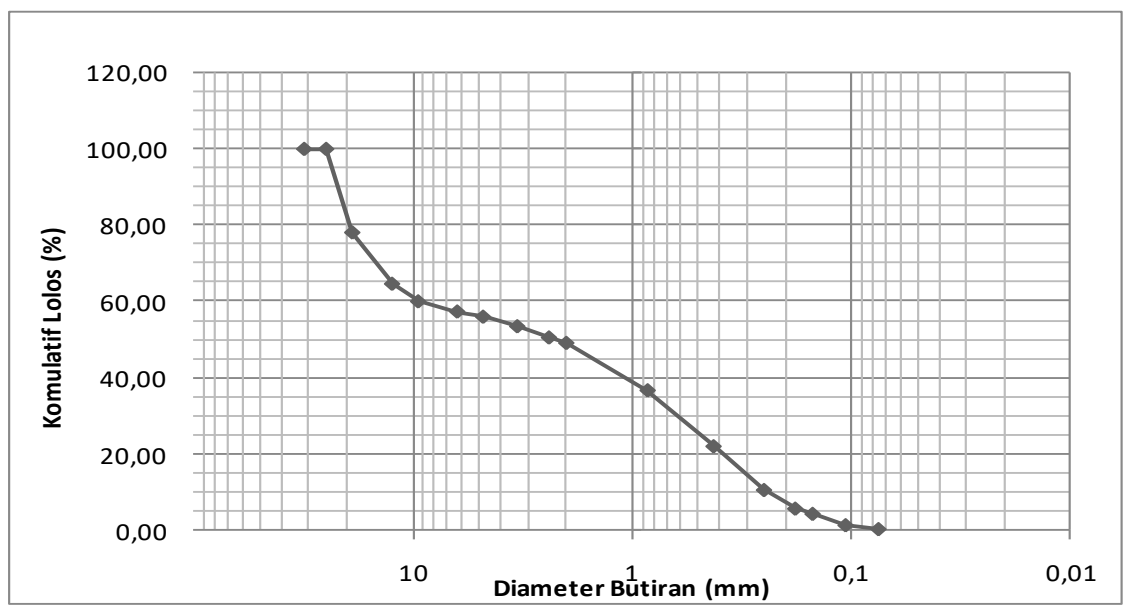

Gambar 4. Kurva Distribusi Komulatif pada Pias 1

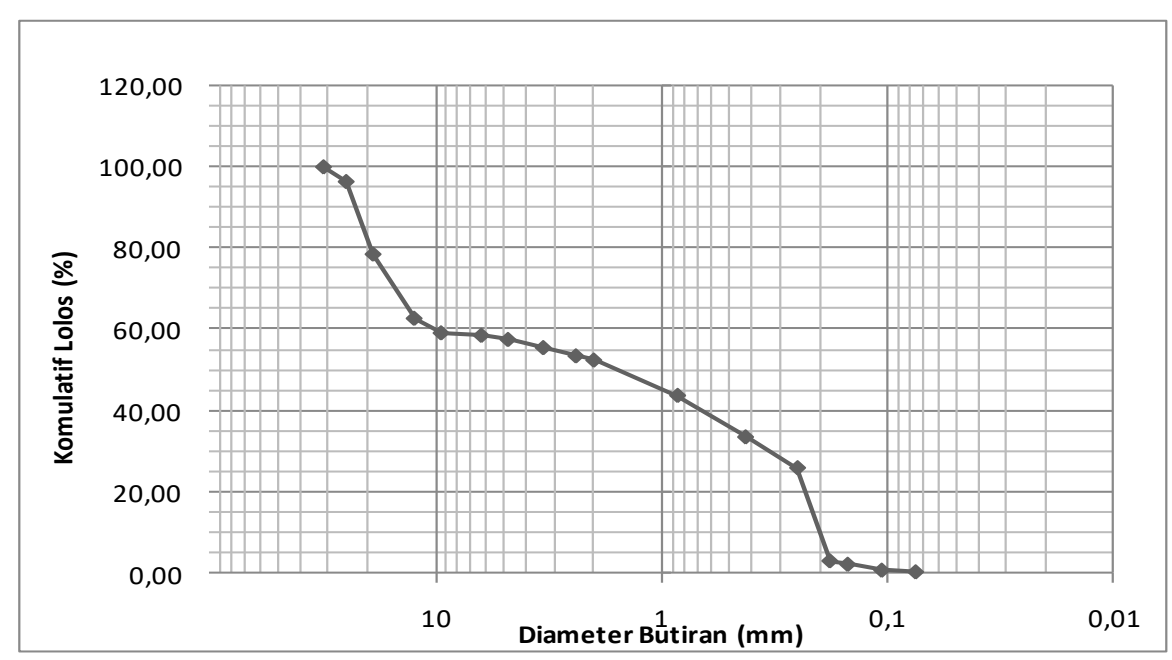

Gambar 5. Kurva Distribusi Komulatif pada Pias 2

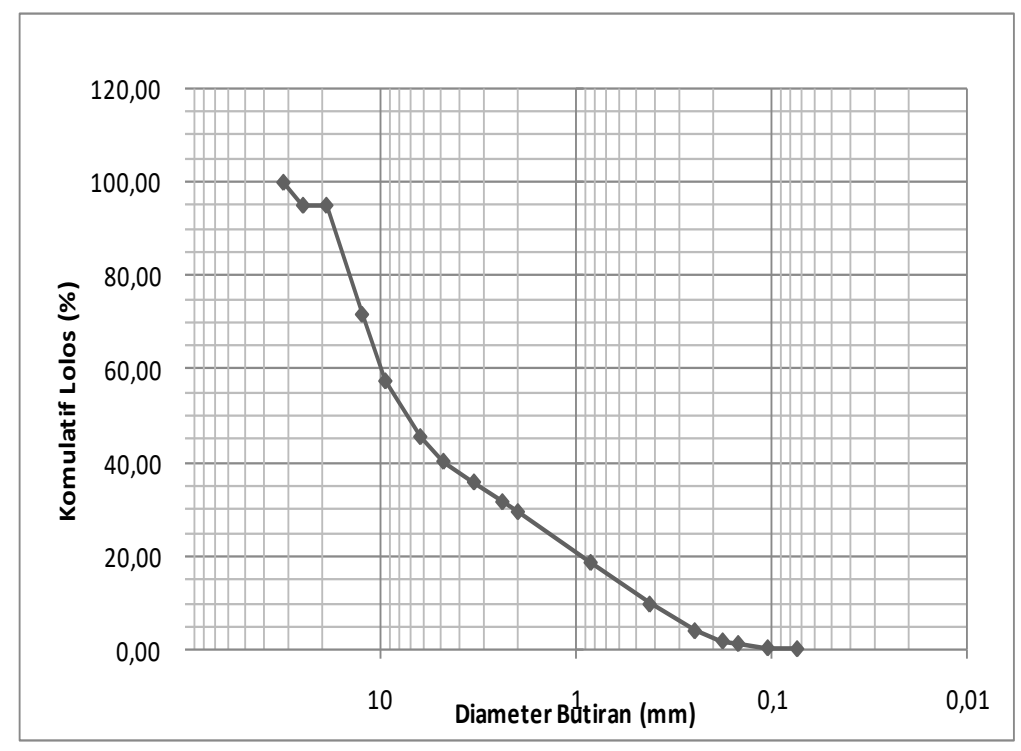

Gambar 6. Kurva Distribusi Komulatif pada Pias 3 
Pada Sungai Belanting survei musim kemarau survei I yaitu didapatkan ukuran butiran sedimen terbesar yang tertahan sebesar 19,57 \% yang termasuk kerikil berkwarsa berukuran 31,5 mm. Dengan cara yang sama untuk sedimen Sungai Belanting pada survei II dapat disajikan pada Tabel 5 berikut ini.

Tabel 5. Distribusi Ukuran Butiran Sungai Belanting Musim Kemarau Survei II

PIAS KANAN

\begin{tabular}{|c|c|c|c|c|c|c|c|}
\hline $\begin{array}{c}\text { No } \\
\text { Saringan } \\
\end{array}$ & $\begin{array}{c}\text { Diameter } \\
\text { Butiran }\end{array}$ & $\begin{array}{c}\text { Berat } \\
\text { Saringan }\end{array}$ & \begin{tabular}{|c|} 
Berat Sampel \\
Tertahan + \\
Saringan \\
\end{tabular} & $\begin{array}{c}\text { Berat } \\
\text { Sampel } \\
\text { Tertahan } \\
\end{array}$ & \begin{tabular}{|c|} 
Berat Sampel \\
KumLolos \\
Saringan \\
\end{tabular} & $\begin{array}{c}\text { Persen } \\
\text { Lolos } \\
\text { Saringan } \\
\end{array}$ & Jenis Material \\
\hline & (mm) & (gr) & (gr) & (gr) & (gr) & (\%) & \\
\hline $11 / 4^{\prime \prime}$ & 31,5 & 459,25 & 459,25 & 0,00 & 504,79 & 100,00 & Kerikil berkwarsa \\
\hline $1 "$ & 25 & 452,79 & 452,79 & 0,00 & 504,79 & 100,00 & Kerikil berkwarsa \\
\hline $3 / 4^{n}$ & 19 & 4688,88 & 604,69 & 135,81 & 368,98 & 73,10 & Kerikil berkwarsa \\
\hline $1 / 2 \pi$ & 12,5 & 450,92 & 552,64 & 101,72 & 267,26 & 52,94 & Kerikil sedang \\
\hline $3 / 8^{\prime \prime}$ & 9,5 & 442,87 & 471,56 & 28,69 & 238,57 & 47,26 & Kerikil sedang \\
\hline $1 / 4^{\pi}$ & 6,3 & 440,67 & 449,08 & 8,41 & 230,16 & 45,60 & Kerikil halus \\
\hline 4 & 4,8 & 429,17 & 434,57 & 5,40 & 224,76 & $\mathbf{4 4 , 5 3}$ & Kerikil halus \\
\hline 6 & 3,35 & 411,7 & 421,09 & 9,39 & 215,37 & 42,67 & Kerikil sangat halus \\
\hline 8 & 2,4 & 394,32 & 405,04 & 10,72 & 204,65 & 40,54 & Kerikil sangat halus \\
\hline 10 & 2 & 395,41 & 399,79 & 4,38 & 200,27 & 39,67 & Pasir sangat berkwarsa \\
\hline 20 & $\mathbf{0 , 8 5}$ & 355,64 & 403,6 & 47,96 & 152,31 & 30,17 & Pasir berkwarsa \\
\hline 40 & 0,425 & 315,66 & 375,85 & 60,19 & 92,12 & 18,25 & Pasir sedang \\
\hline 60 & 0,25 & 285,22 & 333,72 & 48,50 & 43,62 & 8,64 & Pasir sedang \\
\hline 80 & 0,18 & 280,59 & 302,03 & 21,44 & 22,18 & 4,39 & Pasir halus \\
\hline 100 & 0,15 & 275,97 & 282,3 & 6,33 & 15,85 & 3,14 & Pasir halus \\
\hline 140 & 0,106 & 272,24 & 283,35 & 11,11 & 4,74 & 0,94 & Pasir sangat halus \\
\hline 200 & 0,075 & 268,7 & 272,16 & 3,46 & 1,28 & 0,25 & Pasir sangat halus \\
\hline Pan & & 318,26 & 319,54 & 1,28 & $\mathbf{0}$ & 0,00 & \\
\hline & & tal & & 504,79 & & & \\
\hline
\end{tabular}

\section{PIAS KIRI}




\begin{tabular}{|c|c|c|c|c|c|c|c|}
\hline $\begin{array}{c}\text { No } \\
\text { Saringan }\end{array}$ & $\begin{array}{l}\text { Diameter } \\
\text { Butiran }\end{array}$ & $\begin{array}{c}\text { Berat } \\
\text { Saringan }\end{array}$ & $\begin{array}{c}\text { Berat Sampel } \\
\text { Tertahan + } \\
\text { Saringan }\end{array}$ & $\begin{array}{c}\text { Berat } \\
\text { Sampel } \\
\text { Tertahan }\end{array}$ & $\begin{array}{c}\text { Berat Sampel } \\
\text { KumLLolos } \\
\text { Saringan }\end{array}$ & $\begin{array}{c}\text { Persen } \\
\text { Lolos } \\
\text { Saringan }\end{array}$ & Jenis Material \\
\hline & (mm) & (gr) & (gr) & (gr) & (gr) & (\%) & \\
\hline $11 / 4^{\prime \prime}$ & 31,5 & 459,25 & 459,25 & $\mathbf{0 , 0 0}$ & 503,91 & 100,00 & Kerikil berkwarsa \\
\hline $1 "$ & 25 & 452,79 & 477,51 & 24,72 & 479,19 & 95,09 & Kerikil berkwarsa \\
\hline $3 / 4^{\prime \prime}$ & 19 & 468,88 & 468,88 & 0,00 & 479,19 & 95,09 & Kerikil berkwarsa \\
\hline $1 / 2^{\prime \prime}$ & 12,5 & 450,92 & 568,15 & 117,23 & 361,96 & 71,83 & Kerikil sedang \\
\hline $3 / 8^{\prime \prime}$ & 9,5 & 442,87 & 513,75 & 70,88 & 291,08 & 57,76 & Kerikil sedang \\
\hline $1 / 4^{\prime \prime}$ & 6,3 & 440,67 & 501,83 & 61,16 & 229,92 & 45,63 & Kerikil halus \\
\hline 4 & 4,8 & 429,17 & 456,39 & 27,22 & 202,7 & 40,23 & Kerikil halus \\
\hline 6 & 3,35 & 411,7 & 433,84 & 22,14 & 180,56 & 35,83 & Kerikil sangat halus \\
\hline 8 & 2,4 & 394,32 & 415,28 & 20,96 & 159,6 & 31,67 & Kerikil sangat halus \\
\hline 10 & 2 & 395,41 & 406,56 & 11,15 & 148,45 & 29,46 & Pasir sangat berkwarsa \\
\hline 20 & 0,85 & 355,64 & 410,34 & 54,70 & 93,75 & 18,60 & Pasir berkwarsa \\
\hline 40 & 0,425 & 315,66 & 360,72 & 45,06 & 48,69 & 9,66 & Pasir sedang \\
\hline 60 & 0,25 & 285,22 & 313,82 & 28,60 & 20,09 & 3,99 & Pasir sedang \\
\hline 80 & 0,18 & 280,59 & 291,71 & 11,12 & 8,97 & 1,78 & Pasir halus \\
\hline 100 & $\mathbf{0 , 1 5}$ & 275,97 & 278,8 & 2,83 & 6,14 & 1,22 & Pasir halus \\
\hline 140 & 0,106 & 272,24 & 276,71 & 4,47 & 1,67 & $\mathbf{0 , 3 3}$ & Pasir sangat halus \\
\hline 200 & 0,075 & 268,7 & 269,72 & 1,02 & 0,65 & $\mathbf{0 , 1 3}$ & Pasir sangat halus \\
\hline Pan & & 318,26 & 318,91 & 0,65 & $\mathbf{0}$ & 0,00 & \\
\hline \multicolumn{4}{|c|}{ Total } & 503,91 & & & \\
\hline
\end{tabular}

PIAS TENGAH

\begin{tabular}{|c|c|c|c|c|c|c|c|}
\hline $\begin{array}{c}\text { No } \\
\text { Saringan } \\
\end{array}$ & $\begin{array}{c}\text { Diameter } \\
\text { Butiran } \\
\end{array}$ & $\begin{array}{c}\text { Berat } \\
\text { Saringan } \\
\end{array}$ & $\begin{array}{c}\text { Berat Sampel } \\
\text { Tertahan + } \\
\text { Saringan } \\
\end{array}$ & $\begin{array}{c}\text { Berat } \\
\text { Sampel } \\
\text { Tertahan } \\
\end{array}$ & $\begin{array}{c}\text { Berat Sampel } \\
\text { Kum_Lolos } \\
\text { Saringan } \\
\end{array}$ & $\begin{array}{c}\text { Persen } \\
\text { Lolos } \\
\text { Saringan } \\
\end{array}$ & Jenis Material \\
\hline & $(\mathrm{mm})$ & (gr) & (gr) & (gr) & (gr) & $(\%)$ & \\
\hline $11 / 4^{n}$ & 31,5 & 459,25 & 558,99 & 99,74 & 406,85 & 80,31 & Kerikil berkwarsa \\
\hline 1" & 25 & 452,79 & 452,79 & 0,00 & 406,85 & 80,31 & Kerikil berkwarsa \\
\hline $3 / 4^{n}$ & 19 & 468,88 & 531,53 & 62,65 & 344,2 & 67,94 & Kerikil berkwarsa \\
\hline $1 / 2^{n}$ & 12,5 & 450,92 & 515,44 & 64,52 & 279,68 & 55,21 & Kerikil sedang \\
\hline $3 / 8^{\prime \prime}$ & 9,5 & 442,87 & 449,14 & 6,27 & 273,41 & 53,97 & Kerikil sedang \\
\hline $1 / 4^{n}$ & 6,3 & 440,67 & 449,8 & 9,13 & 264,28 & 52,17 & Kerikil halus \\
\hline 4 & 4,8 & 429,17 & 434,54 & 5,37 & 258,91 & 51,11 & Kerikil halus \\
\hline 6 & 3,35 & 411,7 & 421,38 & 9,68 & 249,23 & 49,20 & \begin{tabular}{|l|} 
Kerikil sangat halus \\
\end{tabular} \\
\hline 8 & 2,4 & 394,32 & 406,01 & 11,69 & 237,54 & 46,89 & Kerikil sangat halus \\
\hline 10 & 2 & 395,41 & 401,25 & 5,84 & 231,7 & 45,74 & Pasir sangat berkwarsa \\
\hline 20 & 0,85 & 355,64 & 409,99 & 54,35 & 177,35 & 35,01 & Pasir berkwarsa \\
\hline 40 & 0,425 & 315,66 & 384,71 & 69,05 & 108,3 & 21,38 & Pasir sedang \\
\hline 60 & 0,25 & 285,22 & 339,71 & 54,49 & 53,81 & 10,62 & Pasir sedang \\
\hline 80 & 0,18 & 280,59 & 305,26 & 24,67 & 29,14 & 5,75 & \begin{tabular}{|l|} 
Pasir halus \\
\end{tabular} \\
\hline 100 & 0,15 & 275,97 & 283,26 & 7,29 & 21,85 & 4,31 & Pasir halus \\
\hline 140 & 0,106 & 272,24 & 286,64 & 14,40 & 7,45 & 1,47 & Pasir sangat hahus \\
\hline 200 & 0,075 & 268,7 & 273,56 & 4,86 & 2,59 & 0,51 & Pasir sangat halus \\
\hline Pan & & 318,26 & 320,85 & 2,59 & 0 & 0,00 & \\
\hline \multicolumn{4}{|c|}{ Total } & 506,59 & & & \\
\hline
\end{tabular}

Dari tabel diatas maka dapat digambarkan grafik komulatif lolos saringan dari masingmasing sampel seperti disajikan pada gambar di bawah ini. 


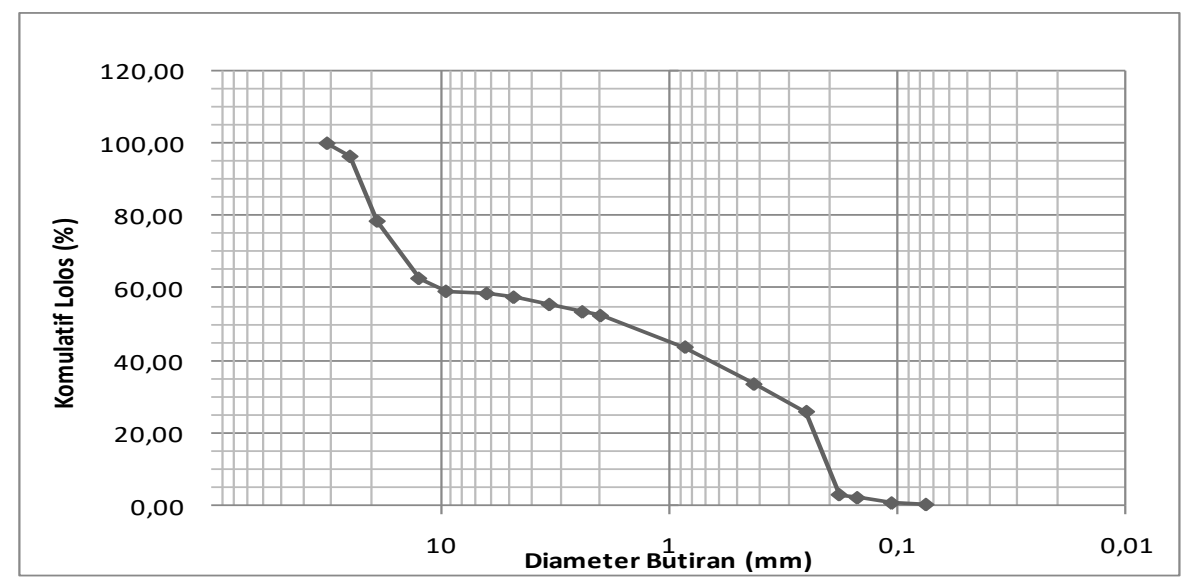

Gambar 7. Kurva Distribusi Komulatif pada Pias 1 Survei II

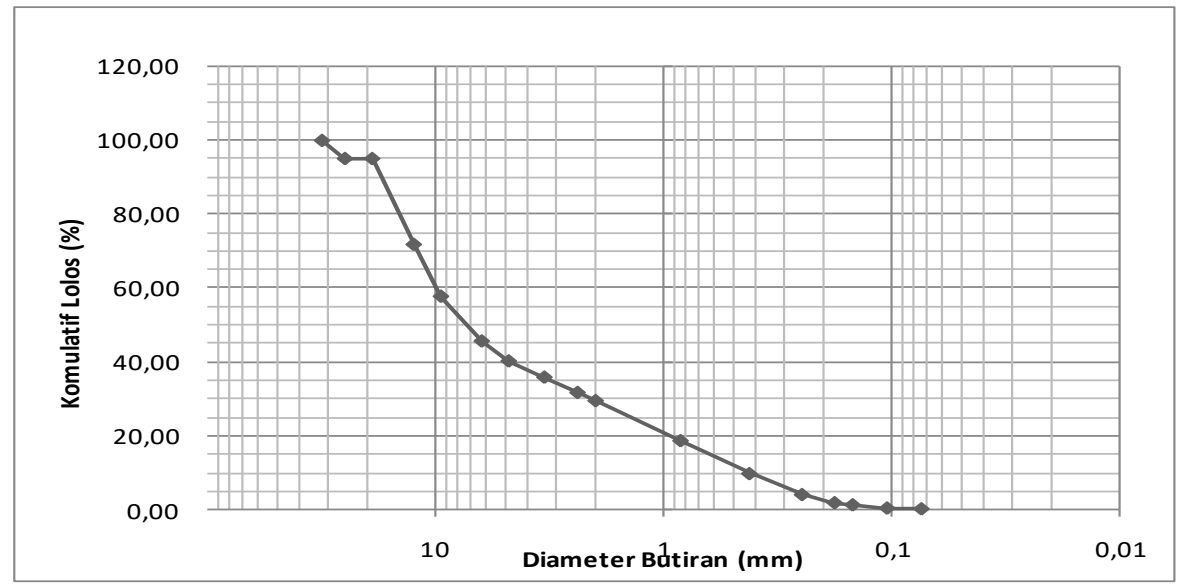

Gambar 8. Kurva Distribusi Komulatif pada Pias 2 Survei II

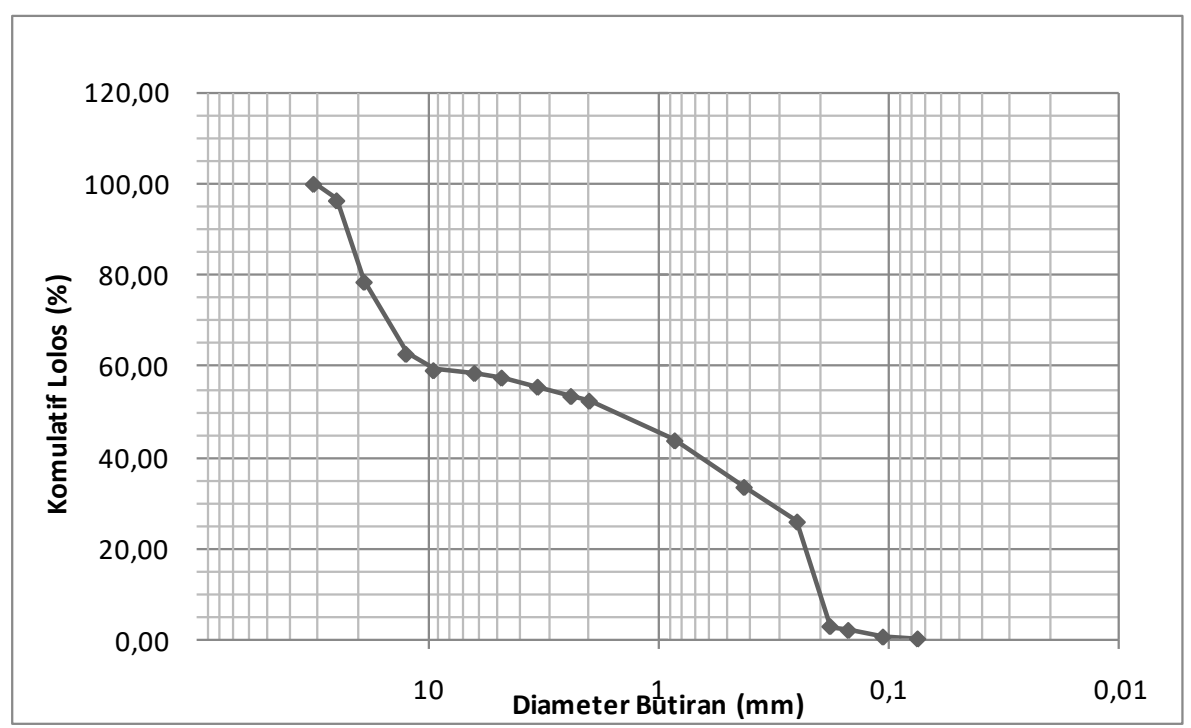

Gambar 9. Kurva Distribusi Komulatif pada Pias 3 Survei II

Pada Sungai Belanting survei musim kemarau survei II yaitu Tabel 4.10 didapatkan ukuran butiran sedimen terbesar yang tertahan sebesar 26,90\% yang termasuk kerikil berkwarsa berukuran $19 \mathrm{~mm}$. 
Pada Gambar 8, persentase lolos saringan untuk musim kemarau dari diameter 0,55 mm pada prosentase lolos 50\% sedangkan survei II pada Gambar 9 prosentase lolos saringan $50 \%$ sebesar 0,65 $\mathrm{mm}$ lebih besar dibanding dengan survei I.

Selain dengan pengamatan secara langsung, untuk mengetahui komposisi distribusi butiran sedimen pada survei I dapat dilihat dari diameter saringan berdasarkan persentase komulatif lolos 50\%, 65\% dan 90\% ( $\mathrm{D}_{50}, \mathrm{D}_{65}$ dan $\left.\mathrm{D}_{90}\right)$ dapat dilihat pada Tabel 6 berikut ini.

Tabel 6. Data Komulatif Lolos dan Diameter Saringan

\begin{tabular}{|c|c|c|c|c|}
\hline \multirow{2}{*}{$\begin{array}{c}\text { Survei I } \\
\text { dan } \\
\text { Survei II }\end{array}$} & \multicolumn{4}{|c|}{$\begin{array}{c}\text { Ukuran } \\
\text { Sedimen Lolos }\end{array}$} \\
\cline { 2 - 5 } & $\mathbf{D _ { 5 0 }}$ & D. & Deterangan \\
\hline \multirow{2}{*}{ Pias 1 } & 2,50 & 20,00 & 20,60 & Kanan \\
\cline { 2 - 5 } & 1,50 & 15,00 & 25,00 & \\
\hline \multirow{2}{*}{ Pias 2 } & 1,50 & 15,00 & 20,80 & Kiri \\
\cline { 2 - 5 } & 7,00 & 12,00 & 18,00 & \\
\hline Pias 3 & 7,00 & 15,00 & 18,00 & Tengah \\
\cline { 2 - 5 } & 1,50 & 15,00 & 24,00 & \\
\hline
\end{tabular}

Untuk data $\mathrm{D}_{50}$, sedimen dari masing-masing pias 1 dapat diartikan bahwa pada pias kanan menunjukan 50 persen dari berat partikel butiran memiliki diameter kurang dari 2,5 $\mathrm{mm}$ yang termasuk dalam jenis kerikil sangat halus hingga pasir sangat berkwarsa.

\section{Berat Jenis (bulk density)}

Untuk mencari besarnya berat jenis angkutan sedimen dasar (bed load) digunakan 2 (dua) pengujian berat jenis dari masing-masing sampel yang ada dengan alat gelas ukur, kemudian dicari rata-ratanya. Pengujian berat jenis dari masing-masing sampel dilakukan di Laboratorium Geologi Teknik dan Geodesi Fakultas Teknik Universitas Mataram. Proses pengujian berat jenis dengan gelas ukur dapat dilihat pada Gambar 10. berikut ini :

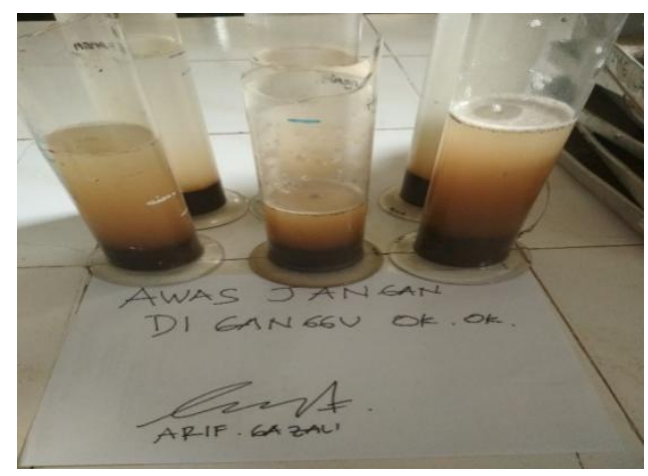

Gambar 10. Proses Pengujian Berat Jenis dengan Gelas Ukur 
Hasil rata-rata berat jenis tersebut adalah 2,496 gram $/ \mathrm{cm}^{3}$.

\section{Kontrol Stabilitas Butiran}

Untuk mengetahui meterial bed load dalam keadaan diam atau bergerak maka diperlukan kontrol butiran. Dalam penelitian ini menggunakan grafik Shields untuk mengetahui nilai kecepatan geser kritis dan tegangan kritisnya.

Untuk mendapatakan nilai $\mathrm{U}^{*}$ cr, penjelasannya dapat dilihat pada grafik Shields :

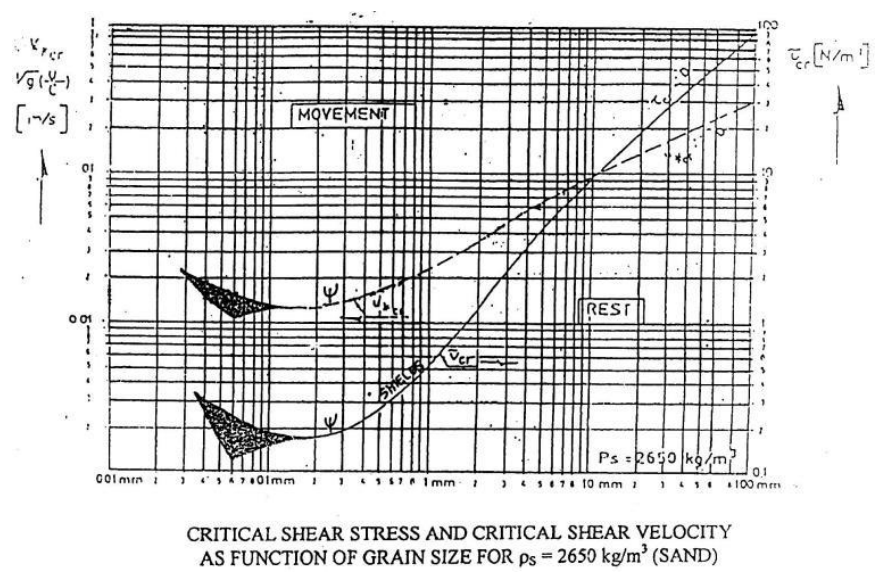

Gambar 11. Grafik Shields untuk Kontrol Stabilitas Butiran pada

Penampang 1Pias Kanan Sungai Belanting

Dari grafik shields, dapat dicari besarnya nilai $\mathrm{U}^{*} \mathrm{cr}$ dengan mengetahui besarnya $\mathrm{D}_{65}$ terlebih dahulu, dimana $\mathrm{D}_{50}=1,50 \mathrm{~mm}$ sehingga $\mathrm{U}^{*}{ }_{\mathrm{cr}}=0,027 \mathrm{~m} / \mathrm{dt}$. Karena nilai $\mathrm{U}^{*}=0,134$ $\mathrm{m} / \mathrm{dt}$, maka $\mathrm{U}^{*}>\mathrm{U}^{*}$ cr, sehingga butiran termasuk butiran bergerak. Untuk kontrol yang lain, langkahnya sama dengan hasil $U^{*}>U^{*}$ cr sehingga butiran termasuk butiran bergerak.

\section{Analisis Angkutan Sedimen Bed Load}

M.P.M melakukan beberapa kali percobaan data flume dengan coarse-sand dan menghasilkan hubungan empiris anatara intensitas angkutan $(\phi)$ dan intensitas pengaliran efektif $\left(\Psi^{\prime}\right)$, sehingga menghasilkan persamaan angkutan sedimen.

Langkah pertama adalah menghitung nilai ripple factor $(\mu)$. Namun sebelumya mencari nilai friction factor yaitu :

$$
\begin{aligned}
C & =\frac{\bar{U}}{\sqrt{R \cdot I}} \\
& =\frac{0,637}{\sqrt{0,237.0,0077}} \\
& =14,911
\end{aligned}
$$

Kemudian, di dapat friction factor intensifnya, yaitu :

$$
\begin{aligned}
C^{\prime} & =18 \log \frac{12 R}{D 90} \\
C^{\prime} & =18 \log \frac{12.0,237}{0,0025} \\
& =38,371
\end{aligned}
$$


Sehingga dapat di hitung ripple factor nya sebagai berikut :

$$
\begin{aligned}
\mu & =\left(\frac{C}{C^{\prime}}\right)^{3 / 2} \\
\mu & =\left(\frac{14,911}{38,371}\right)^{3 / 2} \\
& =0,2423
\end{aligned}
$$

Kemudian menghitung nilai intensitas pengaliran efektif yaitu :

$$
\begin{aligned}
\Psi^{\prime} & =\frac{\mu \cdot R \cdot I}{\left(\Delta \cdot D_{55}\right)} \\
& =\frac{0,02423 \times 0,237 \times 0,0077}{1,496 \times 0,00025} \\
& =0,106
\end{aligned}
$$

Selanjutnya menghitung intensitas angkutan sedimen $(\phi)$ dihitung yaitu :

$$
\begin{aligned}
\phi & =\left(4 \Psi^{\prime}-0,188\right)^{3 / 2} \\
& =(4 \times 0,106-0,188)^{3 / 2} \\
& =0,3407
\end{aligned}
$$

Dengan demikian jumlah sedimen yang terangkut paermeter persatuan waktu dapat dihitung yaitu :

$$
\begin{aligned}
S & =\left(\Phi\left(g \cdot \Delta \cdot D_{55}{ }^{3}\right)^{1 / 2}\right) \\
& =\left(0,3407 \times\left(9,81 \times 1,946 \times 0,00280^{3}\right)^{1 / 2}\right) \\
& =0,0003312801 \mathrm{~m}^{3} / \mathrm{dt} / \mathrm{m}
\end{aligned}
$$

Kemudian menghitung jumlah angkutan sedimen dalam sehari yaitu :

$$
\begin{aligned}
\text { S1 hari } & =S .24 .3600 \\
& =0,0003312801.24 .3600 \\
& =28,623 \mathrm{~m}^{3} / \text { hari. }
\end{aligned}
$$

Dari perhitungan diatas,jumlah angkutan sedimen yang terjadi di penampang 1 pias kanan Sungai Belanting sebesar 28,623 $\mathrm{m}^{3} /$ hari, pias tengah Sungai Belanting sebesar $14,824 \mathrm{~m}^{3} /$ hari dan pias kiri Sungai Belanting sebesar $16,838 \mathrm{~m}^{3} /$ hari, sehingga maksimal angkutan sedimen yang terjadi pada Sungai Belanting survei I sebesar 28,623 $\mathrm{m}^{3} / \mathrm{hari}$. Perbedaan jumlah angkutan sedimen ini disebabkan oleh kecepatan yang berbeda pada setiap 
piasnya, sehingga semakin besar kecepatan aliran pada saluran maka semakin besar pula pergerakan angkutan sedimennya.

\section{PENUTUP}

Beberapa kesimpulan pokok telah didapatkan dalam penelitian ini. Beberapa kesimpulan tersebut adalah sebagai berikut.

1. Volume maksimum angkutan sedimen dasar Sungai Belanting yang ditinjau melalui pengukuran di lapangan sebesar $28,623 \mathrm{~m}^{3} /$ hari

2. Persamaan lengkung-aliran Sungai Belanting yang ditinjau berdasarkan kondisi debit sesaat yang terjadi selama penelitian semakin besar debit aliran, sebesar, $\mathrm{Qw}=3,304$ $\mathrm{m}^{3} / \mathrm{dt}$ maka semakin besar debit sedimen yang terjadi pada penampang Sungai Belanting sebesar, Qs-28,623 $\mathrm{m}^{3} /$ hari

3. Hasil perhitungan angkutan sedimen pada musim kemarau sangat kecil dibandingan dengan debit sedimen yang diambil sebagai Galian C.

\section{DAFTAR PUSTAKA}

Asdak, C. (2010). Hidrologi dan Pengelolaan Daerah Aliran Sungai. Gadjah Mada University Press. Yogyakarta.

PP 35/91. Peraturan Pemerintah Republik Indonesia Nomer 35 Tahun 1991 tentang Sungai. Lembaran Negara Republik Indonesia Tahun 1991 Nomer 44.

PP 37/12. Peraturan Pemerintah Republik Indonesia Nomor 37 Tahun 2012 tentang Pengelolaan Daerah Aliran Sungai. Lembaran Negara Republik Indonesia Tahun 2012.

Priyantoro, D. (1987). Teknik Pengangkutan Sedimen. Fakultas Teknik Universitas Brawijaya, Malang.

Putra, G.I.B. (2003). "Karakteristik Sedimen Bed Load Gunung Berapi Rinjani (Debris Flow) dan Sedimen Lahan pada DAS Tanggik". Fakultas Teknik. Universitas Mataram.

Putra, G.I.B, (2008). "Model Eksperimental Tentang Armouring pada Dasar Sungai (The Experimental Model of Armouring in River Bed)". Jurnal Rekayasa Vol. 9 No. 2; ISSN : 1411-5565; Desember 2008. Fakultas Teknik Unram.

Suprayitno, H. \& Soemitro, R.A.A. (2018). "Preliminary Reflexion on Basic Principle of Infrastructure Asset Management”. Jurnal Manajemen Aset Infrastruktur \& Fasilitas, Vol. 2, No. 1, Maret 2018, Hal. : 1-9. 
(e)ISSN 2615-1847 (p)ISSN 2615-1839

Jurnal Manajemen Aset Infrastruktur \& Fasilitas - Vol. 3, Edisi Khusus 1, Maret 2019 